\title{
VALIDASI METODE PENETAPAN KADAR ASIKLOVIR DALAM SEDIAAN SALEP MENGGUNAKAN KROMATOGRAFI CAIR KINERJA TINGGI (KCKT)
}

\author{
Anita Dwi Puspitasari ${ }^{1 *}$, Sumantri $^{2}$, Putri Nara Aqidah Pawae ${ }^{1}$ \\ ${ }^{1}$ Fakultas Farmasi, Universitas Wahid Hasyim \\ Jl. Menoreh Tengah X/22, Sampangan, Semarang 50236. \\ ${ }^{2}$ Fakultas Farmasi, Universitas Gadjah Mada \\ Sinduadi, Mlati, Kabupaten Sleman, Daerah Istimewa Yogyakarta 55281 \\ Email: anita@unwahas.ac.id
}

\begin{abstract}
Abstrak
Asiklovir merupakan derivat guanosin yang berkhasiat untuk pengobatan infeksi virus herpes. Namun penelitian tentang validasi metode penetapan kadar acyclovir masih jarang dilakukan, maka perlu adanya pengembangan. Tujuan penelitian ini adalah melakukan validasi metode penetapan kadar asiklovir menggunakan KCKT dan aplikasinya dalam sediaan salep. Validasi penetapan kadar salep asiklovir menggunakan KCKT dengan kolom $C_{18}$ dan fase gerak hasil optimasi campuran asetonitril:asam fosfat (80:20 v/v) dan detektor uv-visibel $254 \mathrm{~nm}$. Uji validasi yang dilakukan meliputi akurasi, presisi, selektivitas, linieritas dan sensitivitas. Metode tervalidasi diaplikasikan pada penetapan kadar salep asiklovir. Hasil penelitian menunjukkan bahwa uji validasi memenuhi persyaratan sebagai berikut : Uji akurasi dengan perolehan kembali 99,603-101,800\%, uji presisi dengan nilai RSD 0,302\%, selektivitas yang baik, linieritas dengan nilai korelasi (r) 0,9998, LOD sebesar $0,282 \mu \mathrm{g} / \mathrm{mL}$ dan $L O Q$ sebesar $0,635 \mu \mathrm{g} / \mathrm{mL}$. Hasil penetapan kadar menggunakan metode KCKT pada sediaan salep diperoleh hasil 104,632\%. Hal ini memenuhi persyaratan kadar yang ditetapkan Farmakope Indonesia Edisi V (2014).
\end{abstract}

Kata kunci: asiklovir, salep, validasi

\section{PENDAHULUAN}

Berbagai infeksi virus pada manusia disebabkan oleh virus herpes. Infeksi dari virus herpes dapat disembuhkan oleh salep asiklovir. Salep asiklovir merupakan derivat guanosin berkhasiat spesifik terhadap virus herpes tanpa mengganggu fisiologi sel-sel normal.

Salepasiklovir sering digunakan oleh masyarakat untuk pengobatan penyakit herpes. Hal ini dikarenakan harganya yang murah dan mudah didapat. Namun penelitian tentang validasi asiklovir dalam sediaan salep masih sangat jarang dilakukan, dan kadar asiklovir dalam sediaan salep sangat kecil yaitu $50 \mathrm{mg}$ dalam 1 gram salep, oleh karena itu perlu dikembangkan.Salah satu pengujian dengan metode yang selektif dan sensitif seperti Kromatografi Cair Kinerja Tinggi (KCKT) diperlukanuntuk menganalisis kadar asiklovir.

Pengembangan dan validasi metode RP-HPLC untuk penentuan valasiklovir hidroklorida dan subtansinya yang terkait dalam formulasi tablet $500 \mathrm{mg}$ yang dilakukan Bhavar, et al (2013) menggunakan fase diam ukuran $150 \times 4,0 \mathrm{~mm}$, fase gerak campuran asam fosfat $1 \%$ dan metanol (90:10) serta menggunakan detektor UV pada panjang gelombang $254 \mathrm{~nm}$ memberikan hasil akurasi presisi, linietritas dan reproduksibilitas yang baik. Tetapi dalam penelitian ini tidak dilakukan uji sensitivitas sehingga LOD dan LOQ tidak diketahui. Validasi metode ini tidak bisa dikatakan valid karena tidak memenuhi salah satu parameter yaitu sensitivitas

Penetapan kadar asiklovir dapat menggunakan metode KCKT dengan fase diam $\mathrm{C}_{18}$ dengan ukuran $250 \mathrm{~mm}$ x $4.6 \mathrm{~mm}$ dan fase gerak campuran ammonium asetat $\mathrm{pH} 4.0$ dan asetonitril pada perbandingan 40:60 v/v. Penelitian yang dilakukan menghasilkan sensitivitas, selektivitas,reproduktifitas, akurasi, presisi,liniearitas, stabilitas, dan spesifisitas (Muralidharan, et al, 2014). Penelitian ini tidak dilakukan optimasi fase gerak campuran ammonium asetat $\mathrm{pH} 4.0$ dan asetonitril pada berbagai konsentrasi. Hal ini akan merusak hasil analisis penetapan kadar asiklovir dalam sediaan salep.

Deteksi dan penentuan asiklovir secara kuantitatif dan kualitatifdalam sediaan tablet sebagian besar dilakukan dengan metode kromatografi cair kinerja tinggi reverse phase (RP-HPLC). Sebelum dilakukan penetapan kadar asiklovir, metode ini harus di validasi 
terlebih dahulu. Validasi metode ini harus memenuhi persyaratan yaitu presisi, akurasi, liniearitas, selektivitas, dan sensitivitas (Harmita, 2004).

Sehubungan hal tersebut maka penelitian ini bertujuan untuk melakukan validasi penetapan kadar asiklovir secara kromatografi cair kinerja tinggi (KCKT) menggunakan fase diam $\mathrm{C}_{18}$ dan fase gerak asetonitril:asam fosfat dengan perbandingan $(80: 20 ; 75: 25$ dan 70:30) v/v serta mengaplikasikannya dalam sediaan salep.

\section{METODOLOGI \\ Bahan dan Alat}

Bahan-bahan yang digunakan dalam penelitian ini adalah baku pembanding asiklovir (Phapros), metanol grade HPLC 100\% (merck), aquabidest, asam fosfat $85 \%$, asam klorida pekat, asetonitril, es batu dan salep yang mengandung asiklovir $250 \mathrm{mg}$.

Alat-alat yang digunakan yaitu Seperangkat KCKT (Jasco) terdiri dari pompa (PU 2080 plus), injektor manual, kolom $\mathrm{C}_{18}$ lichrosper 100 , reverse phase $\mathrm{C}_{18}(100 \mathrm{~mm} \mathrm{x}$ 4,6 mm ID, $5 \mu \mathrm{m}$ ), detektor UV (2070 plus),dan pengolah data pada komputer (Ezchromelite), spektrofotometer UV-Vis (1800 Shimadzu), syringe (Hamilton), timbangan analitik (Ohaus), penyaring eluen (Whatman), digital ultrasonic cleaner (Jeken), mikropipet (Socorex), dan alat-alat gelas yang lazim digunakan di laboratorium analitik.

\section{Pembuatan Larutan Stok Baku Asiklovir}

Ditimbang asiklovir sebanyak $50 \mathrm{mg}$, kemudian dilarutkan kedalam labu ukur $250 \mathrm{ml}$. Kemudian ditambahkan dengan fase gerak asam fosfat : asetonitril $(80: 20 \mathrm{v} / \mathrm{v})$ sampai tanda batas sehingga diperoleh konsentrasi 200 $\mu \mathrm{g} / \mathrm{ml}$ (Ravisankar, et al, 2015).

\section{Penentuan Panjang Gelombang Maksimum}

Larutan stok baku asiklovir $200 \mu \mathrm{g} / \mathrm{ml}$ dipipet $100 \mu \mathrm{L}$ kemudian dimasukkan ke dalam labu takar 10,0 mL. Kemudian diencerkan dengan metanol sampai tanda batas sehingga diperoleh larutan asiklovir $2 \mu \mathrm{g} / \mathrm{ml}$. Larutan discanning menggunakan spektrofotometer UV pada panjang gelombang 200-300 nm. Setelah itu dipilih panjang gelombang yang maksimum.

\section{Pembuatan Fase Gerak \\ Pembuatan fase gerak dengan perbandingan asetonitril:asam fosfat $=80: 20$}

$\mathrm{v} / \mathrm{v}$ dibuat dengan cara sebanyak $200 \mathrm{ml}$ asetonitril dimasukkan ke dalam labu takar 250 ml. Kemudian sebanyak $50 \mathrm{ml}$ asam fosfat ditambahkan kedalam labu takar berisi asetonitril, lalu dihomogenkan dengan digital ultrasonic cleaner pada suhu $30^{\circ} \mathrm{C}$ selama 15 menit.

Pembuatan fase gerak dengan perbandingan asetonitril:asam fosfat $=75: 25 \mathrm{v} / \mathrm{v}$ dibuat dengan cara sebanyak 187,5 ml asetonitril dimasukkan kedalam labu takar 250 $\mathrm{ml}$. Kemudian sebanyak $62,5 \mathrm{ml}$ asam fosfat ditambahkan kedalam labu takar berisi asetonitril, lalu dihomogenkan dengan digital ultrasonic cleaner pada suhu $30^{\circ} \mathrm{C}$ selama 15 menit.

Pembuatan fase gerak dengan perbandingan asetonitril:asam fosfat $=70: 30 \mathrm{v} / \mathrm{v}$ dibuat dengan cara sebanyak $175 \mathrm{ml}$ asetonitril dimasukkan kedalam labutakar $250 \mathrm{ml}$. Kemudian sebanyak $75 \mathrm{ml}$ asam fosfat ditambahkan kedalam labu takar berisi asetonitril, lalu dihomogenkan dengan digital ultrasonic cleaner pada suhu $30^{\circ} \mathrm{C}$ selama 15 menit (Bhavar, et al, tahun 2014).

\section{Optimasi Fase Gerak}

Optimasi campuran fase gerak terdiri dari asetonitril:asamfosfat dengan perbandingan asetonitril:asam $\quad \operatorname{fosfat}(80: 20 \quad \mathrm{v} / \mathrm{v})$; asetonitril:asam fosfat $(75: 25 \mathrm{v} / \mathrm{v})$ dan asetonitril:asam fosfat $(70: 30 \mathrm{v} / \mathrm{v})$. Kemudian dipilih perbandingan fase gerak yang memberikan hasil resolusi yang terbaik. Laju alir yang digunakan adalah $1 \mathrm{~mL} / \mathrm{menit}$ (Ravisankar et al, 2015).

\section{Pembuatan Kurva Baku}

Larutan stok baku asiklovir $200 \mu \mathrm{g} / \mathrm{mL}$ dipipet sebanyak $100 \mu \mathrm{L}, 200 \mu \mathrm{L}, 300 \mu \mathrm{L}, 400$ $\mu \mathrm{L}, \quad 500 \mu \mathrm{L}$, dan $600 \mu \mathrm{L}$, masing-masing dimasukkan kedalam labu takar $10 \mathrm{~mL}$. Kemudian masing-masing larutan stok tersebut ditambah fase gerak campuran asetonitril:asamfosfat $(80: 20 \mathrm{v} / \mathrm{v})$ sampai tanda batas dan kocok hingga homogen sehingga diperoleh kadar Asiklovir $2 \mu \mathrm{g} / \mathrm{mL}, 4 \mu \mathrm{g} / \mathrm{mL}, 6$ $\mu \mathrm{g} / \mathrm{mL}, 8 \mu \mathrm{g} / \mathrm{mL}, 10 \mu \mathrm{g} / \mathrm{mL}, 12 \mu \mathrm{g} / \mathrm{mL}$. Lalu masing-masing larutan disaring dengan membrane penyaring nylon $0,2 \mu \mathrm{m}$, dan diinjeksikan kesistem KCKT dengan volume penyuntikan $20 \mu \mathrm{L}$ (Ravisankar,et al, 2015).

\section{Validasi \\ a. Uji Ketelitian}


Larutan yang mengandung Asiklovir 10 $\mu \mathrm{g} / \mathrm{mL}$ diinjeksikan sebanyak $20 \mu \mathrm{L}$ ke alat KCKT. Uji ini dilakukan replikasi sebanyak 6 kali. Kemudian dicacat hasil uji berupa luas area, waktu retensi, lebar dan tinggi puncak. Selanjutnyadihitung presentase koefisien variasinya.

\section{b. Uji Ketepatan}

Uji ketepatan dilakukan dengan metode penambahan baku (standard addition method) yaitu dengan membuat 3 konsentrasi analit sampel dengan penambahan baku $80 \%$ setara dengan $40 \mu \mathrm{g} / \mathrm{mL}, 100 \%$ setara dengan 50 $\mu \mathrm{g} / \mathrm{mL}$ dan $120 \%$ setara dengan $60 \mu \mathrm{g} / \mathrm{mL}$, dimana masing-masing dilakukan 3 kali replikasi. Masing-masing sebanyak $20 \mu \mathrm{L}$ diinjeksikan kedalam KCKT.

\section{c. Uji Linieritas}

Larutan baku Asiklovir dengan konsentrasi $2 ; 4 ; 6 ; 8 ; 10$ dan12 $\mu \mathrm{g} / \mathrm{mL}$, diinjeksikan sebanyak $20 \mu \mathrm{L}$ ke alat KCKT. Luas area dari puncak Asiklovir yang diperoleh setiap konsentrasinya dibuat persamaan regresi linier, dan dihitung koefisien korelasinya. Uji linieritas dilakukan 3 kali pengulangan. Persamaan garis linier yang paling baik digunakan sebagai persamaan kurva baku dalam menetapkan kadar sampel.

\section{d. Uji Selektivitas}

Larutan yang mengandung Asiklovir diinjeksikan sebanyak $20 \mu \mathrm{L}$ kealat KCKT. Berdasarkan kromatogram dapat dilihat puncak analit Asiklovir dan komponen lainnya dalam salep dapat terpisah dengan sempurna. Selektivitas metode dapat ditentukan melalui perhitungan daya resolusinya (Rs).

\section{e. Uji Sensitivitas}

Larutan yang mengandung Asiklovir konsentrasi $2 ; 4 ; 6 ; 8 ; 10$; dan $12 \mu \mathrm{g} / \mathrm{mL}$ diinjeksikan sebanyak $20 \mu \mathrm{L}$ kealat KCKT. Uji sensitivitas dinyatakan dengan uji batas deteksi (LOD) dan batas kuantifikasi (LOQ). Batas deteksi dan batas kuantifikasi metode dihitung secara statistik menggunakan persamaan garis regresi linier yang diperoleh dari uji linieritas.

\section{Penetapan Kadar Asiklovir dalam Sediaan Salep}

Proses ekstrasi dilakukan dengan cara Asiklovir ditimbang sebanyak 1 gram, kemudian dilarutkan dengan $50 \mathrm{ml}$ aquabidest suasana asam $\mathrm{HCl}$. Lalu dipanaskan larutan dalam tabung reaksi selama beberapa menit, setelah itu dibekukan dengan es. Untuk memisahkan zat maka disentrifugasi pada30 rpm selama 15 menit. Disaring masing-masing dengan membrane filter $0,45 \mu \mathrm{m}$. Kemudian larutan sampel diambil $1 \mathrm{ml}$ diarutkan dengan fase gerak sebanyak $50 \mathrm{ml}$. Sampel dianalisis dengan menggunakan KCKT dengan fase gerak asetonitril:asam fosfat $(80: 20 \mathrm{v} / \mathrm{v})$ dan fase diam $\mathrm{C}_{18}$. Detektor diatur pada panjang gelombang $254 \mathrm{~nm}$. Sebanyak $20 \mu \mathrm{L}$ diinjeksikan dengankecepatanalir $1 \mathrm{~mL} /$ menit. Penetapan kadar sampel dilakukan sebanyak 6 kali pengulangan untuk salep sampel. Dihitung kadar Asiklovir dengan mensubstitusikan luas area sampel Y kedalam persamaan regresi linier $\mathrm{y}=\mathrm{bx}+\mathrm{a}$ (Ravisankar, et al 2015 dan Ghosh, et al, 2012).

\section{HASIL DAN PEMBAHASAN \\ Penentuan Panjang Gelombang Maksimum}

Hasil scanning larutan asiklovir menunjukkan serapan maksimum pada panjang gelombang 254,90 $\mathrm{nm}$. Panjang gelombang maksimum larutan asiklovir dapat dilihat pada Gambar 1.

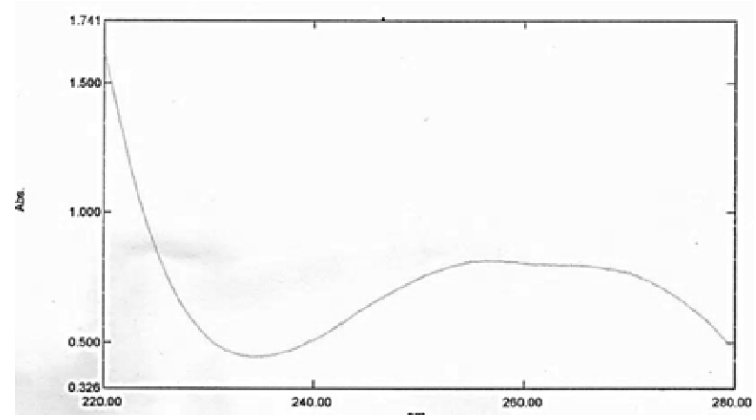

\section{Gambar 1. Hasil Scanning Panjang Gelombang Maksimum Asiklovir Menggunakan Spektrofotometri UV}

Panjang gelombang maksimum tersebut sama dengan penelitian yang dilakukan Somsubhra G., et al(2015) yaitu larutan asiklovir menunjukkan serapan maksimum pada panjang gelombang $254 \mathrm{~nm}$.

\section{Optimasi Komposisi Fase Gerak}

Optimasi fase gerak dilakukan dengan merubah perbandingan fase gerak sehingga mampu ditemukan komposisi fase gerak umumnyayang tepat untuk asiklovir yaitu 
campuran asetonitril : asam fosfat dengan perbandingan 80:20 v/v, 75:25 $\mathrm{v} / \mathrm{v}$ dan 70:30 $\mathrm{v} / \mathrm{v}$. Deteksi dilakukan dengan panjang gelombang 254,90 $\mathrm{nm}$ dan laju alir $1 \mathrm{ml} /$ menit. Hasil optimasi komposisi fase gerak dapat dilihat pada Tabel 1 dan kromatogram fase gerak optimum dapat dilihat pada Gambar 2.

Tabel 1. Hasil Optimasi Komposisi Fase Gerak

\begin{tabular}{cccc}
\hline $\begin{array}{c}\text { Komposisi fase } \\
\text { gerak (asam } \\
\text { fosfat:asetonitril) }\end{array}$ & $\begin{array}{c}\text { RT } \\
\text { (menit) }\end{array}$ & $\begin{array}{c}\text { Luas } \\
\text { puncak }\end{array}$ & Keterangan \\
\hline $80: 20$ & 1,933 & 2018773 & Optimum \\
$75: 25$ & 2,033 & 1879095 & \\
$70: 30$ & 2,023 & 1734538 & \\
\hline
\end{tabular}

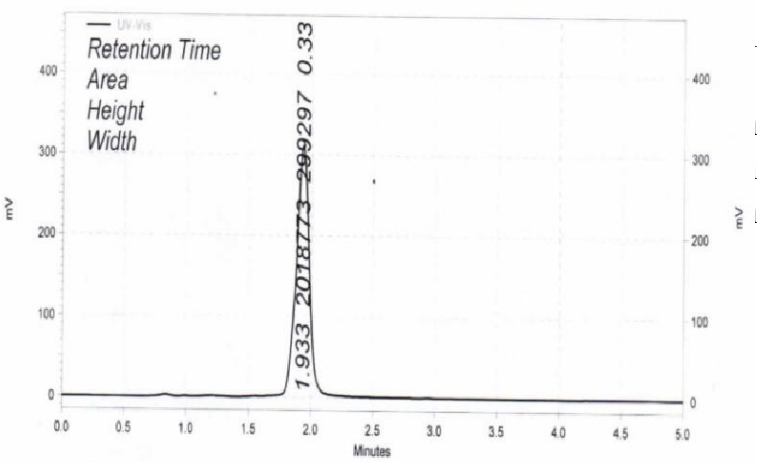

Gambar 2. Kromatogram Hasil Optimasi Komposisi Fase Gerak Optimum Asetonitril:Asam Fosfat (80:20 v/v)

Fase gerak yang terpilih adalah fase gerak dengan perbandingan asetonitril:asam fosfat $(80: 20 \mathrm{v} / \mathrm{v})$ karena memiliki waktu retensi yang cepat, luas puncak yang cukup luas dan puncak yang simetris.

\section{Pembuatan Kurva Baku Asiklovir}

Kurva baku menghasilkan persamaan regresi linier $\mathrm{y}=52932.53 \mathrm{x}+16615.47$ dengan koefisien korelasi $r=0,9997$. Grafik kurva baku asiklovir dapat dilihat pada gambar 3 .

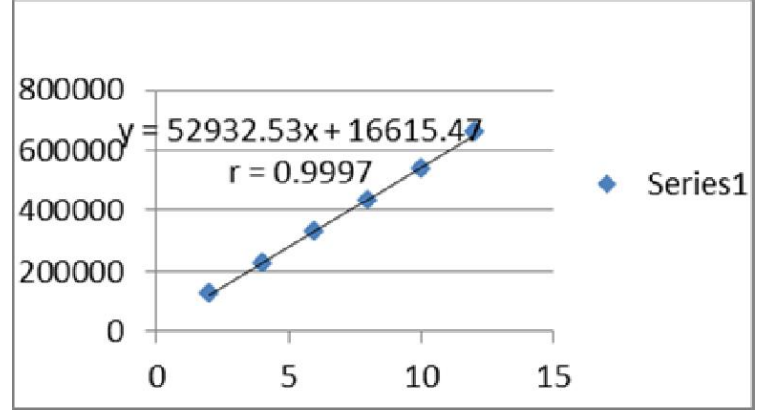

Gambar 3. Grafik Kurva Baku Asiklovir

Grafik diatas menunjukkan linieritas yang mendekati angka 1 yaitu 0.9997 dengan sumbuY adalah luas puncak area kromatogram asiklovir dan sumbu $\mathrm{X}$ adalah kadar.

\section{Uji Validasi}

\section{a. Uji Ketelitian (Presisi)}

Uji presisi ditentukan berdasarkan nilai RSD (Relative Standard Deviasi), uji ketelitian menghasilkan nilai RSD sebesar 0,302\%. Hasil yang diperoleh menunjukkan bahwa metode analisis yang divalidasi memenuhi persyaratan nilai RSD dan menunjukkan ketelitian yang baik yaitu nilai RSD kurang dari 2\% (Harmita, 2004).Hasil uji ketelitian asiklovir dapat dilihat pada Tabel 2.

\section{Tabel 2. Hasil Uji Ketelitian (Presisi)}

\begin{tabular}{|c|c|c|c|c|}
\hline $\begin{array}{l}\text { kadar } \\
(\mathrm{ppm})\end{array}$ & $\begin{array}{l}\text { waktu } \\
\text { retensi } \\
\text { (menit) }\end{array}$ & luas area & $\begin{array}{c}\text { tinggi } \\
\text { puncak }\end{array}$ & Kadar \\
\hline 10 & 1.910 & 437868 & 79047 & 7.96 \\
\hline 10 & 1.197 & 439230 & 85522 & 7.98 \\
\hline 10 & 1.917 & 436521 & 85441 & 7.93 \\
\hline 10 & 1.910 & 436824 & 79031 & 7.94 \\
\hline 10 & 1.910 & 436602 & 78963 & 7.93 \\
\hline 10 & 1.917 & 439230 & 85522 & 7.98 \\
\hline \multicolumn{4}{|c|}{ Rata-rata } & 7.96 \\
\hline \multicolumn{4}{|c|}{ SD } & 0.02 \\
\hline \multicolumn{4}{|c|}{$\%$ RSD } & $0.302 \%$ \\
\hline
\end{tabular}

\section{b. Uji Ketepatan (Akurasi)}

Uji akurasi ditentukan melalui uji perolehan kembali dengan metode penambahan bahan baku pada analit. Perolehan kembali dihitung dengan membandingkan jumlah asiklovir terukur untuk masing-masing penambahan baku terhadap kadar baku asiklovir yang ditambahkan. Untuk asiklovir, nilai range akurasinya yaitu antara 98- 
$102 \%$.Hasil perolehan kembali pada tingkat tiga

kosentrasi dapat dilihat pada Tabel 3.

Tabel 3. Hasil Uji Akurasi Asiklovir

\begin{tabular}{cccccc}
\hline $\begin{array}{c}\text { sampel : } \\
\text { bahan baku }\end{array}$ & Replikasi & Perolehan kembali (\%) & $\begin{array}{c}\text { Rata- } \\
\text { rata }\end{array}$ & D & RSD \\
\hline \multirow{2}{*}{$100: 80$} & 1 & 101.584 & & & \\
& 2 & 101.203 & 101.292 & 0.262 & $0.258 \%$ \\
& 3 & 101.089 & & & \\
$100: 100$ & 1 & 101.981 & & & \\
& 2 & 101.612 & 101.788 & 0.180 & $0.177 \%$ \\
$100: 120$ & 3 & 101.799 & & & \\
& 1 & 99.631 & & & \\
& 2 & 99.582 & 99.603 & 0.023 & $0.023 \%$ \\
\hline
\end{tabular}

keterangan :

$\mathrm{A}=$ kosentrasi sampel yang diperoleh setelah penambahan bahan baku (total)

$\mathrm{B}=$ kosentrasi sampel sebelum penambahan bahan baku

$\mathrm{C}=$ kosentrasi bahan baku yang ditambahkan

\section{c. Linieritas}

Uji linieritas dilakukan pada 6 konsentrasi asiklovir yaitu 2, 4, 6, 8, 10 dan 12 $\mu \mathrm{g} / \mathrm{mL}$ dengan melakukan replikasi sebanyak 3 kali. Hasil uji linieritas dapat dilihat pada Tabel 4.

\section{Tabel 4. Hasil Uji Linieritas}

\begin{tabular}{cc}
\hline Replikasi & Regresi linier \\
\hline 1 & $\mathrm{a}=14355.93$ \\
& $\mathrm{~b}=53320.98$ \\
& $\mathrm{r}=0,9996$ \\
2 & $\mathrm{a}=17476.13$ \\
& $\mathrm{~b}=52501.31$ \\
& $\mathrm{r}=0,9998$ \\
3 & $\mathrm{a}=10768.33$ \\
& $\mathrm{~b}=54125$ \\
& $\mathrm{r}=0,9995$ \\
\hline
\end{tabular}

Berdasarkan tabel diatas dapat diketahui bahwa ketiga garis regresi linier menunjukkan korelasi yang baik dengan koefisien korelasi (r) memenuhi kriteria yang dimana nilai $r$ dapat diterima yaitu $r+1$ atau -1 (Harmita, 2004). Persamaan garis regresi yang paling baik berdasarkan nilai $\mathrm{r}$ adalah $\mathrm{y}=$ $52932.53 \mathrm{x}+16615.47 ; \mathrm{r}=0.9997$.

\section{d. Selektivitas}

Selektivitas dapat dinyatakan dengan derajat penyimpangan dari metode yang dilakukan terhadap larutan pembanding yang mengandung bahan yang ditambahkan.Semakin besar nilai resolusi maka pemisahan komponenkomponen yang terelusi dengan waktu retensi yang berdekatan semakin efisien. Hasil kromatogram asiklovirdapat dilihat pada gambar 4.

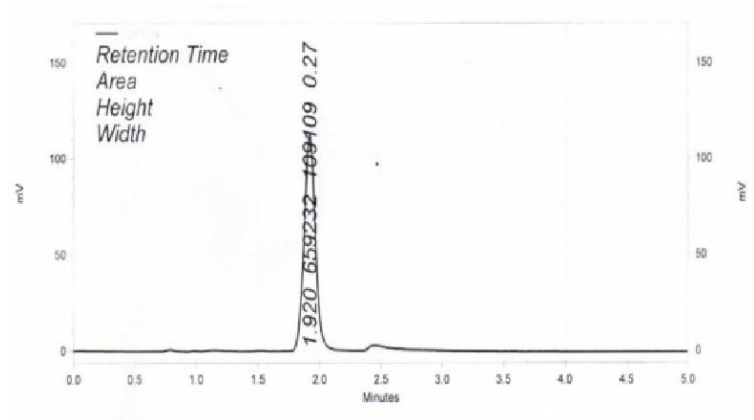

Gambar 4. Hasil kromatogram asiklovir 
Berdasarkan hasil kromatogram diatas diketahui bahwa hanya ada 1 puncak saja dari asikloviryang dapat diukur sedangkan komponen lain tidak ada yang terukur. Metode analisis memiliki selektivitas yang baik karena dapat mengukur asiklovir secara tepat.

\section{e. Sensitivitas}

Uji sensitivitas dinyatakan dengan uji batas deteksi (LOD) dan batas kuantifikasi (LOQ). Batas deteksi dan batas kuantifikasi dihitung berdasarkan hasil dari persamaan garis regresi linier, yaitu $y=52501.31 x+17476.13$ dan koefisen korelasi (r) $=0.9998$.LOD menunjukkan konsentrasi analit terendah dalam sampel yang mampu dideteksi dengan persamaan $\mathrm{Y}=\mathrm{Y}_{\mathrm{B}}+3 \mathrm{~S}_{\mathrm{B}}$. Sedangkan LOQ menunjukkan kuantitas terkecil analit dalam sampel yang masih dapat memenuhi kriteria cermat dan seksama dengan persamaan $\mathrm{Y}_{\mathrm{B}}+10$ $\mathrm{S}_{\mathrm{B} .}$

Konsentrasi yang sudah ditentukan (2$12 \mu \mathrm{g} / \mathrm{mL}$ ) dimasukkan dalam persamaan kurva baku asiklovir $\mathrm{y}=52501.31 \mathrm{x}+17476.13$. Berdasarkan perhitungan kurva baku, diperoleh nilai LOD asikloviradalah $0,282 \mu \mathrm{g} / \mathrm{mL}$ sedangkan nilai LOQ asikloviradalah 0,635 $\mu \mathrm{g} / \mathrm{mL}$ (lampiran 3). Sedangkan penelitian sebelumnya yang dilakukan Ravisankar,et al, (2015) diperoleh nilai LOD $0,2470 \mu \mathrm{g} / \mathrm{mL}$ dan LOQ $0,7486 \mu \mathrm{g} / \mathrm{mL}$. Nilai ini cukup memadai untuk analisis kualitatif asiklovir dengan menggunakan KCKT.

Metode penetapan kadar asiklovir dengan menggunakan KCKT yang dilakukan menunjukkan bahwa presisi, akurasi, selektivitas, sensitivitas dan linieritas memenuhi persyaratan. Sehingga dapat disimpulkan bahwa validasi metode untuk penetapan kadarasiklovirtelah tervalidasi maka dapat dipastikan metode yang dilakukan dapat digunakan untuk menetapkan kadar asiklovir.

\section{Penetapan Kadar Asiklovir dalam Sediaan Salep}

Penetapan kadar asiklovir dalam sediaan salep menggunakan KCKT dihitung dengan cara memplotkan luas area (Y) sampel dengan masing-masing kurva baku yang telah diperoleh yaitu $\mathrm{y}=\mathrm{y}=$ $52932.53 x+16615.47$

Hasil perhitungan kadar asiklovir dalam sediaan salep dapat dilihat pada Tabel 5.
Tabel 5. Kadar Asiklovir

\begin{tabular}{llll}
$\begin{array}{c}\text { Sam } \\
\text {-pel }\end{array}$ & $\begin{array}{l}\text { Luas } \\
\text { Puncak }\end{array}$ & $\begin{array}{l}\text { Kandungan } \\
\text { asiklovir } \\
\text { dalam } \\
\text { sampel (mg) }\end{array}$ \\
& & g & Kadar \% \\
\hline 1 & 554471 & 254.029 & 508.058 \\
2 & 581799 & 266.936 & 533.872 \\
3 & 558276 & 255.826 & 511.652 \\
4 & 587696 & 269.721 & 539.442 \\
5 & 554471 & 254.029 & 508.058 \\
6 & 586034 & 268.936 & 537.872 \\
& Rata-rata & 261.580 & 104.632 \\
& SD & 1.539 & 3.079 \\
& RSD & 0.029 & $2.943 \%$ \\
\hline
\end{tabular}

Kadar yang telah diperoleh memenuhi persyaratan yang tercantum dalam Farmakope Indonesia Edisi V (2014), yaitu asiklovir mengandung tidak kurang dari $90,0 \%$ dan tidak lebih dari $110,0 \%$.

\section{KESIMPULAN}

Validasi metode penetapan kadar asiklovir menggunakan KCKT dengan fase diam $\mathrm{C}_{18}$ dan fase gerak campuran asetonitril : asam fosfat dengan perbandingan $80: 20 \mathrm{v} / \mathrm{v}$ dengan laju alir $1 \mathrm{~mL} / \mathrm{menit}$, panjang gelombang $254 \mathrm{~nm}$ dan volume injeksi $20 \mu \mathrm{L}$ dapat dilakukan.

Metode validasi di atas dapat memenuhi persyaratan validasi, yaitu memberikan hasil uji sebagai berikut : Uji presisi RSD 0,302\%, uji akurasi 99,603-101,800\%, uji selektivitas menghasilkan luas puncak yang tajam, waktu retensi yang pendek, uji linieritas dengan (r) 0,9998 pada kisaran kosentrasi $2-12 \mu \mathrm{g} / \mathrm{mL}$, dengan LOD sebesar $0,282 \mu \mathrm{g} / \mathrm{mL}$ dan LOQ sebesar $0,635 \mu \mathrm{g} / \mathrm{mL}$.

Metode yang sudah divalidasi tersebut dapat diaplikasikan pada penetapan kadar asiklovir dalam sediaan salep dengan hasil kadar rata-rata asiklovir pada sediaan salep adalah 104,632 \%. Hal ini memenuhi persyaratan kadar yang ditetapkan Farmakope Indonesia Edisi V (2014). 
DAFTAR PUSTAKA

Anonim, (2014), Farmakope Indonesia Edisi V. Departemen Kesehatan Republik Indonesia, Jakarta.

Anief, M., (2006), Ilmu Meracik Obat, Gajah Mada University Press, Yogyakarta.

Ansel, H.C., (1989), Pengantar Bentuk Sediaan Farmasi, Edisi 4, Universitas Indonesia UI-press, Jakarta.

Ardiningsih, R., (2009), Penggunaan High Performance Liquid Chromatography (HPLC) dalam Proses Analisis Deteksi Ion, Penelitian Bidang Dirgantara, Pusterapan, LAPAN.

Anonim, (2008), Informatorium Obat Nasional Indonesia, Badan Pengawasan Obat Dan Makanan Republik Indonesia, Jakarta.

Bhavar B. G.,PekamwarS., S., Aher1 B., K., Chaudhari1 R. S., (2014), Development and Validation of RPHPLC Method for the Determination of Valacyclovir Hydrochloride and its Related Substances in Tablet Formulation, International Journal of Pharmaceutical Sciences Review and Research,53-58.

Food and Drug Administration \& Centre for Drug Evaluation and Research, (2001), Guidance For Industry Bioanalytical Method Validation, http://www.fda.gov/downloads/Drug $s$ Guidance Compliance Regulatory Information/Guidance/UCM070107. pdf, diakses 11 Januari 2012.

Gandjar, I.G., dan Rohman, A., (2007), Kimia Farmasi Analisis, Cetakan II, Pustaka Pelajar, Yogyakarta, 246.

Ghosh S., Sahu A., Kumar S., D., Jena S., harani A., Reddy K., P., T.,Tanuja D., (2012), Method Development And Validation For Acyclovir In Tablet Dosage Form By RP-HPLC, India.

Harmita, (2004), Petunjuk Pelaksanaan Validasi Metode Dan Cara
Perhitungannya, Majalah Ilmu Kefarmasiaan, Vol.I, No. 3, 117128.

Miller, J.C., and Miller, J.N., (1998), Statistics for Analytical Chemistry, $2^{\text {nd }}$ Edition, John Wiley \& Sons, New York, 109-120.

Muralidharan S., Kalaimani J., Parasuraman S., Dhanaraj A., S., (2014), Development and validation of Acyclovir HPLC External Standard Method in Human Plasma Application to Pharmacocinetic Studies, Hindiawi.

Putra, E.D., (2007), Kromatografi Cair Kinerja Tinggi Dalam Bidang Farmasi, Fakultas Farmasi Universitas Sumatera Utara, Medan.

Ravisangkar P. Niharik A., Sireesha A., Khoushik S., O., Himaja G., (2015), Development And Validation Of RP-HPLC Method For Quantitative Estimation Of Acyclovir In Bulk Drug And Tablets, Hindiawi.

Rohman, A., (2009), Kromatografi Untuk Analisis Obat, Ghara Ilmu, Yogyakarta.

Sastrohamodjojo, H., (2002), Kromatografi, Universitas Gadjah Mada, Yogyakarta, 67-77.

Snyder, R.L., Kirkland, J.J., and Glajch, J.L., (1997), Practical HPLC Method Development, $2^{\text {nd }}$ Edition, John Wiley \& Son, Inc., New York, 686-697. 